\title{
The role of epidermal differentiation gene complex studies in atopic dermatitis
}

\author{
Atopik dermatitte epidermal farkılașma gen kompleksi çalıșmalarının rolü
}

\section{๑ Özge Gündüz, ๑ Deepak Modi, ๑ Raquel Duarte*}

University of the Witwatersrand Faculty of Health Sciences, Department of Internal Medicine, Division of Dermatology; *Department of Internal Medicine, Internal Medicine Research Laboratory, Johannesburg, South Africa

\begin{abstract}
Atopic dermatitis (AD) is a chronic skin disease affecting mainly children with an increasing prevalence worldwide. AD is a complex trait resulting from genetic predisposition, skin barrier dysfunction, immune dysregulation, and environmental factors. The major risk factors for $A D$ are a family history of atopy (eczema, asthma, or allergic rhinitis) and the loss-of-function mutations in the filaggrin (FLG) gene. This review highlights the role of the genetic abnormalities identified in $A D$, from the susceptibility loci in genome-wide associations to epigenetic studies. Keywords: Atopic dermatitis, genetics, epidermal differentiation gene complex, filaggrin

Öz

Atopik dermatit $(A D)$, dünya çapında yaygınlığı artmış çocukları etkileyen kronik bir deri hastalığıdı. $A D$, genetik yatkınlık, deri bariyeri işlev bozukluğu, immün disregülasyon ve çevresel faktörlerin etkileşiminden kaynaklanan karmaşık bir özelliktir. AD için başlıca risk faktörleri, ailede atopi öyküsü (egzama, astım veya alerjik rinit) ve filagrin ( $F L G)$ genindeki fonksiyon kaybı mutasyonlarıdır. Bu derleme, genom çapında ilişkilendirme çalışmalarındaki duyarılık lokuslarından epigenetik çalıșmalara kadar tanımlanan genetik anormalliklerin AD'deki rolünü vurgulamaktadır.

Anahtar Kelimeler: Atopik dermatit, genetik, epidermal farklılaşma gen kompleksi, filaggrin
\end{abstract}

\section{Introduction}

Atopic dermatitis [AD, (MIM 603165)] is the most common chronic inflammatory skin disease affecting between $(0.2$ $30 \%$ ) of children worldwide. Data in developing countries is lacking, but its increasing prevalence is noted. This presents a major public health problem worldwide ${ }^{1}$. AD usually manifests during infancy with a varied clinical presentation and is dependent on the patients' age. It has a chronic relapsing course over months to years. In addition, lesions compatible with acute, sub-acute, and chronic eczema may be evident in the same patient at the same time?

$A D$ is a complex trait resulting from genetic predisposition, skin barrier dysfunction, immune dysregulation, and environmental factors. The epidermal skin barrier is a gatekeeper that prevents excessive water loss, assists with temperature regulation, and restricts immunological "invasion" by microbes. The pathogenesis of $A D$ involves abnormalities in the pathophysiology of this barrier.

Address for Correspondence/Yazışma Adresi: Özge Gündüz MD, University of the Witwatersrand University Faculty of Health Sciences, Department of Internal Medicine, Division of Dermatology, Johannesburg, South Africa Phone: +27712196923 E-mail: drozgegunduz@yahoo.com Received/Geliş Tarihi: 06.09.2020 Accepted/Kabul Tarihi: 08.12.2020 ORCID: orcid.org/0000-0001-8541-9246

Cite this article as: Gündüz Ö, Modi D, Duarte R. The role of epidermal differentiation gene complex studies in atopic dermatitis. TurkdermTurk Arch Dermatol Venereol 2021;55:56-60.

(C) Copyright 2021 by Turkish Society of Dermatology and Venereology

Turkderm - Turkish Archives of Dermatology and Venereology published by Galenos Yayınevi. 
Inflammation with an increased Thelper 2 (Th2) response to allergens presented following the above abnormalities leads to the manifestations of $A D^{3}$. The major risk factors for $A D$ are a family history of atopy (eczema, asthma, or allergic rhinitis) and the loss-of-function mutations in the FLG [FLG, (MIM 135940)] gene that is essential for maintaining skin barrier function $)^{4}$.

This review summarizes the genetic abnormalities identified in $A D$, from susceptibility loci in genome-wide associations (GWAS) to epigenetic studies. We aim to highlight the role of epidermal differentiation complex (EDC) genes in the pathogenesis of $A D$.

\section{Epidermal skin barrier proteins in atopic dermatitis}

Profilaggrin, a large repetitive polyprotein, is the main component of keratohyaline granules in the stratum granulosum layer of the epidermis. During terminal differentiation of granular cells to flattened squames of the stratum corneum, profilaggrin is processed into multiple free $37 \mathrm{kDa}$ filaggrin monomers that condense the cytoskeleton of the skin. FLG is broken down by chemical modification and proteolytic processing within the squames and forms a natural moisturizing factor, a natural humectant within the residual cytoplasmic space of the squames ${ }^{5}$. The FLG gene is located on chromosome 1q21 within the EDC genes that encode the structural epidermal proteins, named S100-fused type proteins, and include profilaggrin, filaggrin-2, hornerin, repetin, trichohyalin, cornulin, and trichohyalin-like $1^{6}$. The FLG gene has three exons, and the profilaggrin protein is encoded by the third exon. It comprises almost identical tandem repeats of about 972 base pairs and has allelic variants of 10, 11, and 12 repeats (Figure 1) ${ }^{7}$. Identifying the link between $A D$ and loss-of-function (LOF) mutations of $F L G$ gene has led to studies on the pathogenetic role of $F L G$ in $A D^{8}$. FLG-null mutations lead to FLG deficiency and cause increased skin permeability, increased penetration of environmental allergens, irritants, and microorganisms, causing an inflammatory response. The LOF mutations in FLG are major risk factors for the early onset of $A D$, more severe disease, and the greater incidence of other allergic diseases, including food allergies and asthma. In two meta-analyses, $A D$ risk was higher in individuals carrying either one or both $\mathrm{R} 501 \mathrm{X}$ and 2282del4 mutations compared with non-carriers ${ }^{9,10}$. Around 10\% of European ancestry individuals carry a single null mutation in $F L G$. The most common LOF mutations in white Europeans are R501X, 2282del4, S3247X, and R2447X4. In European populations, carriage of one or more FLG LOF mutations results in three times increased risk for $\mathrm{AD}^{4}$, indicating a substantial effect for a single gene in a disease of a complex trait.

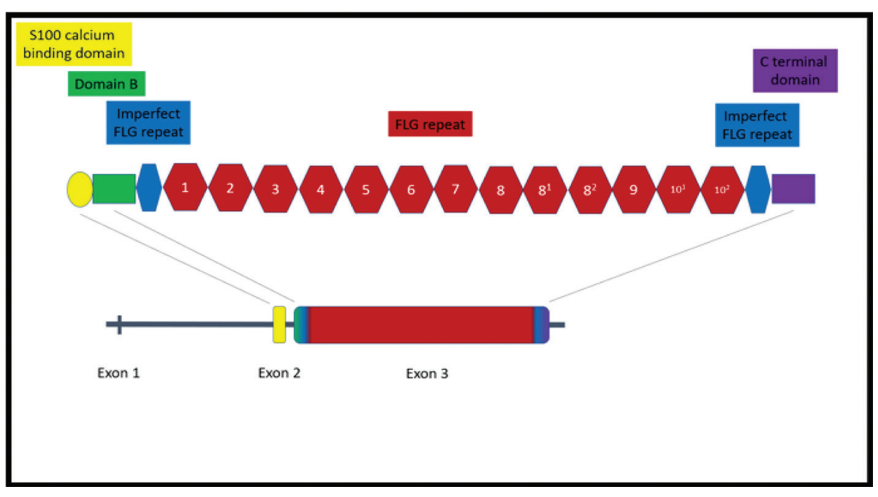

Figure 1. The structure of the filaggrin $(F L G)$ gene
In contrast, in populations from Asia, Africa, or African ancestry, the FLG mutations that are highly prevalent in European patients are uncommon, and unique FLG mutations in these ethnic groups were found '. The R501X mutation in the FLG gene is not seen in any of the children in the $A D(n=49)$ and control $(n=50)$ groups in a sample population of Turkish children ${ }^{11}$. In addition, the mutations in the FLG gene and the copy number variations or epigenetic regulation of FLG were shown to modulate FLG expression. The low intragenic copy number variation of $F L G$ in different ethnic groups of patients with $A D$ correlates with disease severity ${ }^{12,13}$.

FLG-2 and hornerin (HRNR) are other proteins critical for the stratum corneum and its barrier function. The expression of FLG-2 and HRNR are significantly reduced in both lesional and non-lesional skin of patients with $A D$ compared with healthy subjects ${ }^{14}$. Recently, novel mutations in FLG and other EDC genes, such as FLG-2 and claudin 1 (CLDN1), were associated with $A D$ patients, with either disease severity or the early onset of $A D$ in children younger than five years old, respectively ${ }^{15,16}$. Immune-mediated skin inflammation does not differ in AD patients with or without FLG mutations. However, the upregulation of Th2 cytokines interleukin-4 (IL-4) and IL-13 leads to the downregulation of FLG expression, causing a FLG deficiency and consequently impairs epidermal barrier function ${ }^{17}$. Treating human keratinocytes with proinflammatory cytokines reduces the expression of proFLG, FLG-2, and HRNR, which negatively affects the cytokines on the epidermal barrier $^{14}$

\section{Genome-wide association studies}

Genome-wide association studies are the methods for identifying genes in complex disorders and have helped identify novel genes for AD (i.e., FLG on chromosome 1p21) 18 . In 2009, the first AD GWAS was conducted in a European population. It detected the locus on chromosome 1 q21.3 (the EDC, including FLG) with a novel susceptibility locus on chromosome $11 \mathrm{q} 13.5^{19}$. The largest meta-analyses of GWAS data on $A D$ in different ethnic groups (European, African, Japanese, Latino, and mixed non-European ancestry) included 21,399 cases and 95,464 controls, with 15 million genetic variants and $31 \mathrm{AD}$ risk loci detected ${ }^{20}$. However, out of 31 risk loci, only three loci (IL-13, FLG, and IL-6R) were coding variants. The function of most GWAS loci remains unclear, but they correlate with skin barrier development and immunological dysfunctions, i.e., innate immune signaling, T-cell activation, and differentiation in acquired immunity ${ }^{20,21}$. Despite recent advances, the loci identified by GWAS explain approximately $15 \%$ of the variance 20,21 . This unaccountable $85 \%$ is called "missing heritability" of complex diseases and may be explained by the marked heterogeneity of $A D$, the cumulative effects of these structural variations and genome copy number variants, and heritable epigenetic mechanisms ${ }^{21}$.

\section{Exome sequencing studies}

With recent advances in next-generation sequencing technologies, the protein-coding region of genes in a genome (called an exome) of an individual can be sequenced (whole-exome sequencing, WES). This allows the study to discover the rare variations in polygenic diseases ${ }^{22}$. On the other hand, the limitation of the exome sequencing studies is that they have shown limited success for complex traits ${ }^{23}$.

To date, few studies of WES analyses of AD focusing on EDC genes have been published. A WES study of 22 Ethiopian patients with ichthyosis vulgaris and $A D$ identified several rare variants consistent 
with a heterogenous disease pathogenesis ${ }^{24}$. Also, the same research group showed an association between the CLDN1 gene and early onset $A D$ (younger than five years old) in their Ethiopian cohort ${ }^{16}$. Another WES that entailed a targeted analyses of the EDC region in 60 African-American children with AD found a FLG-2 variant associated with a more persistent phenotype ${ }^{25}$. In a WES study of a cohort of three families, Heo et al. ${ }^{26}$ identified both rare and common variants of the COL6A6 gene as possible novel candidates for early onset AD in Koreans. In the same study, missense mutations of FLG [A3262T, Q3520P (rs80088153)] and FLG-2 [C298S (rs2282302)] were found in three families on chromosome one. In another WES study, 13 LOF FLG variants (five were novel) were identified in 21 of the 43 probands of 42 Bangladeshi families residing in the United Kingdom ${ }^{27}$.

These findings show that WES is effective for identifying rare population-specific variants. However, it must be considered that these studies were done in a limited number of patient cohorts with specific ethnicities. It thus might be difficult to replicate these results in other populations ${ }^{28}$.

\section{Transcriptome analyses}

The accessibility of skin tissue has enabled the comparison of gene expression patterns between lesional, non-lesional, and normal skin. Gene expression profiling assays, namely RNA-sequencing technology, have improved the analyses and quantification of mRNA over those of the past with previous microarray studies ${ }^{29}$. High-throughput gene expression profiling showed that the expression of keratinocyte differentiation genes was dysregulated (i.e., downregulation of FLG and involucrin; up regulation of loricrin) in $A D$ skin biopsy specimens compared with healthy controls ${ }^{1}$. In a transcriptome profiling study using RNA-sequencing, differences in genes expressed between $A D$ and normal skin were reported in pathways involving lipid metabolism, the extracellular space, and the stress response. When the transcriptome data were stratified according to FLG genotype, FLG deficient skin expressed a type-1 interferon-mediated stress response ${ }^{30}$. A meta-analyses of four microarray studies (meta-analyses derived AD transcriptome) shed light on novel key AD pathways; atherosclerosis signaling (IL-37, selectin-E, S100A8), lipid abnormalities (FA2H, ELOVL3), and negative correlations between the expression of Th2 cytokines and epidermal lipids ${ }^{31}$. In another study using transcriptome data from public databases, Ghosh et al. ${ }^{32}$ presented an 89 gene panel that could be utilized as a signature for $A D$. The differentially regulated genes were categorized into the following functional classes: (a) barrier function-related genes, e.g., LOR, LCE2B; (b) dysregulated lipid genes, e.g., FABP7, FADS1; (c) chemokine/cytokine genes, e.g., CCL17, CCL18; (d) protease and protease-inhibitor genes, e.g., SERPINB3, $K L K 5$; (e) anti-microbial function, e.g., LTF, MSMB; and (f) genes with diverse metabolic functions, e.g., ARGAP18 ${ }^{32}$. In a study of rare-protein variants employing exome chip and replication genotype data of 15,574 AD patients and 377,839 controls, Mucha et al. ${ }^{33}$ identified CD200 receptor 1 (CD200R1) and (DOK2) as two novel susceptibility genes.

Transcriptomic profiling studies of AD found that using full-thickness skin biopsies leads to an over representation in the expression of epidermisspecific genes due to epidermal hyperplasia. In contrast, dermis-specific genes are found to be underrepresented ${ }^{34}$. This bias also results in the up regulation of false positives or down regulation of false negatives.
This could be overcome by using laser capture microdissection to achieve compartment-specific transcriptional profiling ${ }^{35}$. Different $A D$ pathways were detected in different patient groups, i.e., Th1 profiles were observed in adult AD patients, whereas enriched Th17-/Th22associated gene profiles (e.g., CCL20, IL36, IL36RN, and IL23) were found in pediatric patients ${ }^{34}$. A similar bias was detected when comparing the manifestation of $A D$ among different ethnic groups. While European-Americans exhibited a Th-1 type AD profile, in AfricanAmerican and Asian AD patients, the TH17 axis was enhanced ${ }^{36}$.

\section{Epigenetic studies}

Epigenetics focuses on heritable changes in DNA expression through DNA methylation, histone modification, and noncoding RNA (microRNA) expression. Abnormal epigenetic gene regulation via methylation involved in innate immune responses and skin barrier functions contributes to the pathogenesis of $A D^{28}$. Hypomethylation of the promoters of FCERG that encode FceR $\gamma$, a high-affinity immunoglobulin E receptor chain, and TSLP, results in the overexpression of these genes in $A D^{22}$. Global DNA hypomethylation and demethylation of regulatory elements of FCER $1 G$ contribute to FceRI overexpression on the monocytes of $A D$ patients ${ }^{37}$. Rodríguez et al..$^{38}$ described significant differences in the methylation pattern for various $\mathrm{CpG}$ islands between lesional $A D$ skin samples versus healthy control skin. However, no significant difference was observed in genome-wide DNA methylation levels of whole blood, B-cell, and T-cell samples obtained from AD cases and controls ${ }^{38}$. Ziyab et al. ${ }^{39}$ reported that methylation levels of the $\mathrm{CpG}$ site had an increased risk of eczema in FLG haploinsufficient individuals compared with those with the wild FLG genotype. However, another study for this apparent role of FLG methylation yielded contradicting results ${ }^{40}$. These conflicting results in DNA methylation findings indicate that blood does not function as an ideal surrogate for skin and demonstrates the roles of tissue-specific epigenomic changes ${ }^{38,41}$.

MicroRNAs (miRNAs) are short, single-stranded RNA molecules that, together with partner proteins, result in the degradation of target mRNAs ${ }^{37}$. The increased expression of miRNA-155 on Th1 and Th2 cells is detected in skin lesions and blood samples of AD patients and is regulated by allergens and superantigens. MiRNA-155 increases Th cell responses by decreasing the expression of cytotoxic T-lymphocyteassociated antigen 4, which is the key molecule that inhibits the T-cell response ${ }^{42}$. MiRNA-146a may also play an important role in AD. It was unregulated in both affected and intact skin ${ }^{43}$. On the other hand, miRNA-143, which was downregulated in skin samples of AD patients, suppressed IL-13-induced inflammation and downregulation of FLG, the epidermal barrier proteins, by targeting its receptor ${ }^{44}$.

\section{Conclusion}

$A D$ is a complex disease trait. Identifying genetic mutations in the FLG gene causing skin barrier dysfunction in 2006 was a pioneering step in understanding its pathogenesis. However, these mutations cannot be shown in every individual with AD. This provides the need for research into explaining the latter. It has also been shown that there are FLG-null mutations specific to different populations.

This challenges earlier studies on the pathogenesis of $A D$ based on European mutations. A study on $A D$ in Turkey analyzed only one 
European FLG-LOF mutation. This highlights the need for further genetic studies that include the cosmopolitan population groups in Turkey. Genes controlling the innate and adaptive immune system are crucial to maintaining the immunological stability of the skin. Polymorphisms of the Th2 signaling pathway genes have been implicated in the pathogenesis and clinical manifestations of $A D$. Polymorphisms of IL-4, IL-13, and IL-31 and their receptors (IL4R $\alpha$ and IL13R $\alpha 1$ ) are associated with an increased risk of $A D$ due to the alternations in signal transduction pathways. The insights gained from these and further genetic studies will enable the development of novel targeted therapies and ultimately lead to individualized treatments for the heterogeneous phenotypes of $A D$.

\section{Ethics}

Peer-review: Externally peer-reviewed.

\section{Authorship Contributions}

Concept: Ö.G., Design: Ö.G., D.M., R.D., Literature Search: Ö.G., Writing: Ö.G., D.M., R.D.

Conflict of Interest: No conflict of interest was declared by the authors.

Financial Disclosure: The authors declared that this study received no financial support.

\section{References}

1. Kaufman BP, Guttman-Yassky E, Alexis AF. Atopic dermatitis in diverse racial and ethnic groups-Variations in epidemiology, genetics, clinical presentation and treatment. Exp Dermatol 2018;27:340-57.

2. McAleer MA, O'Regan GM, Irvine AD: Atopic dermatitis. Dermatology. Ed. Bolognia JL, Schaffer JV, Cerroni L. 4th Edition. Elsevier, 2018;208-27.

3. Weidinger S, Novak N: Atopic Dermatitis. Lancet 2016;387:1109-22.

4. Irvine $A D$, McLean $W H$, Leung DY: Filaggrin mutations associated with skin and allergic diseases. N Eng J Med 2011:365:1315-27.

5. McLean WH: Filaggrin failure-from ichthyosis vulgaris to atopic eczema and beyond. Br J Dermatol 2016;175(Suppl 2):4-7.

6. Cabanillas B, Novak N: Atopic dermatitis and filaggrin. Curr Opinion Immunol 2016;42:1-8.

7. Mathyer ME, Quiggle AM, Wong XFCC, et al: Tiled array-based sequencing identifies enrichment of loss-of-function variants in the highly homologous filaggrin gene in African-American children with severe atopic dermatitis. Exp Dermatol 2018;27:989-92.

8. Palmer $C N$, Irvine $A D$, Terron-Kwiatkowski A, et al: Common loss-of-function variants of the epidermal barrier protein filaggrin are a major predisposing factor for atopic dermatitis. Nat Genet 2006;38:441-6.

9. Rodríguez $E$, Baurecht $H$, Herberich $E$, et al: Meta-analysis of filaggrin polymorphisms in eczema and asthma: robust risk factors in atopic disease. J Allergy Clin Immunol 2009;123:1361-70.e7.

10. van den Oord RA, Sheikh A: Filaggrin gene defects and risk of developing allergic sensitisation and allergic disorders: systematic review and metaanalysis. BMJ 2009;339:b2433.

11. Ercan $H$, Ispir $T$, Kirac $D$, et al: Predictors of atopic dermatitis phenotypes and severity: roles of serum immunoglobulins and filaggrin gene mutation R501X. Allergol Immunopathol (Madr) 2013;41:86-93.

12. Brown SJ, Kroboth K, Sandilands A, et al: Intragenic copy number variation within filaggrin contributes to the risk of atopic dermatitis with a dosedependent effect. J Invest Dermatol 2012;132:98-104.

13. Quiggle AM, Goodwin ZA, Marfatia TR, et al: Low filaggrin monomer repeats in African American pediatric patients with moderate to severe atopic dermatitis. JAMA Dermatol 2015;151:557-9.

14. Pellerin L, Henry J, Hsu CY, et al: Defects of filaggrin-like proteins in both lesional and nonlesional atopic skin. J Allergy Clin Immunol 2013;131:1094102.
15. Margolis DJ, Gupta J, Apter AJ, et al: Exome sequencing of filaggrin and related genes in African-American children with atopic dermatitis. J Invest Dermatol 2014;134:2272-4.

16. Asad $S$, Winge $M C$, Wahlgren $C F$, et al: The tight junction gene Claudin-1 is associated with atopic dermatitis among Ethiopians. J Eur Acad Dermato Venereol 2016;30:1939-41.

17. Howell MD, Kim BE, Gao P, et al: Cytokine modulation of atopic dermatitis filaggrin skin expression. J Allergy Clin Immunol 2007;120: 150-5.

18. Portelli MA, Hodge E, Sayers I: Genetic risk factors for the development of allergic disease identified by genome-wide association. Clin Exp Allergy 2014; $45: 21-31$

19. Esparza-Gordillo J, Weidinger S, Fölster-Holst R, et al: A common variant on chromosome $11 q 13$ is associated with atopic dermatitis. Nat Genet 2009;41:596-601.

20. Paternoster L, Standl M, Waage J, et al: Multi-ancestry genome-wide association study of 21,000 cases and 95,000 controls identifies new risk loci for atopic dermatitis. Nat Genet 2015;47:1449-56.

21. Løset M, Brown SJ, Saunes M, Hveem K: Genetics of atopic dermatitis: From DNA sequence to clinical relevance. Dermatology 2019;235:355-64.

22. Bin L, Leung DY: Genetic and epigenetic studies of atopic dermatitis. Allergy Asthma Clin Immunol 2016;12:52.

23. Stemmler S, Hoffjan S: Trying to understand the genetics of atopic dermatitis. Mol Cell Probes 2016;30:374-85.

24. Taylan F, Nilsson D, Asad S, et al: Whole-exome sequencing of Ethiopian patients with ichtyosis vulgaris and atopic dermatitis. J Allergy Clin Immunol 2015;136:507-9.

25. Margolis DJ, Gupta J, Apter AJ, et al: Filaggrin-2 variation is associated with more persistent atopic dermatitis in African American subjects. J Allergy Clin Immunol 2014;133:784-9.

26. Heo WI, Park $K Y$, Jin $T$, et al: Identification of novel candidate variants including COL6A6 polymorphisms in early-onset atopic dermatitis using whole-exome sequencing. BMC Med Genet 2017;18:8.

27. Pigors $M$, Common JEA, Wong XFCC, et al: Exome sequencing and rare variant analysis reveals multiple filaggrin mutations in bangladeshi families with atopic eczema and additional risk genes. J Invest Dermatol 2018;138:2674-7.

28. Stemmler S, Hoffjan S: Trying to understand the genetics of atopic dermatitis. Mol Cell Probes 2016;30:374-85.

29. Brown SJ: Molecular mechanisms in atopic eczema: Insights gained from genetic studies. J Pathol 2017;241:140-5.

30. Cole C, Kroboth K, Schurch NJ, et al: Filaggrin-stratified transcriptomic analysis of pediatric skin identifies mechanistic pathways in patients with atopic dermatitis. J Allergy Clin Immunol 2014;134:82-91.

31. Ewald DA, Malajian D, Krueger JG, et al: Meta-analysis derived atopic dermatitis (MADAD) transcriptome defines a robust $A D$ signature highlighting the involvement of atherosclerosis and lipid metabolism pathways. BMC Medical Genomics 2015;8:60.

32. Ghosh D, Ding L, Sivaprasad U, et al: Multiple transcriptome data analysis reveals biologically relevant atopic dermatitis signature genes and pathways. PLoS One 2015;10:e0144316.

33. Mucha S, Baurecht $H$, Novak N, et al: Protein-coding variants contribute to the risk of atopic dermatitis and skin-specific gene expression. J Allergy Clin Immunol 2020;145:1208-18.

34. Schwingen J, Kaplan M, Kurschus FC: Review-current concepts in Inflammatory skin diseases evolved by transcriptome analysis: In-depth analysis of atopic dermatitis and psoriasis. Int J Mol Sci 2020;21:699.

35. Esaki H, Ewald DA, Ungar B, et al: Identification of novel immune and barrier genes in atopic dermatitis by means of laser capture microdissection. J Allergy Clin Immunol 2015;135:153-63.

36. Sanyal RD, Pavel $A B$, Glickman J, et al: topic dermatitis in African American patients is TH2/TH22-skewed with $\mathrm{TH} 1 / \mathrm{TH} 17$ attenuation. Ann Allergy Asthma Immunol 2019;122:99-110.

37. Liang $Y$, Chang $C$, Lu Q. the genetics and epigenetics of atopic dermatitisfilaggrin and other polymorphisms. Clin Rev Allergy Immunol 2016;51:315-28. 
38. Rodríguez $\mathrm{E}$, Baurecht $\mathrm{H}$, Wahn $A F$, et al: $A n$ integrated epigenetic and transcriptomic analysis reveals distinct tissue-specific patterns of DNA methylation associated with atopic dermatitis. J Invest Dermatol 2014;134:1873-83

39. Ziyab AH, Karmaus W, Holloway JW, Zhang H, Ewart S, Arshad SH: DNA methylation of the filaggrin gene adds to the risk of eczema associated with loss-of-function variants. J Eur Acad Dermatol Venereol 2013;27:e420-3.

40. Tan HT, Ellis JA, Koplin JJ, et al: Methylation of the filaggrin gene promoter does not affect gene expression and allergy. Pediatr Allergy Immunol 2014;25:608-10
41. Ghosh D, Bernstein JA, Khurana Hershey GK, Rothenberg ME, Mersha TB. Leveraging multilayered "omics" data for atopic dermatitis: a road map to precision medicine. Front Immunol 2018;9:2727.

42. Ma L, Xue HB, Wang F, Shu CM, Zhang JH: MicroRNA-155 may be involved in the pathogenesis of atopic dermatitis by modulating the differentiation and function of T helper type 17 (Th17) cells. Clin Exp Immunol 2015;181:142-9.

43. Rożalski M, Rudnicka L, Samochocki Z: MiRNA in atopic dermatitis. Postepy Dermatol Alergol 2016;33:157-62.

44. Zeng $Y P$, Nguyen $G H$, Jin HZ: MicroRNA-143 inhibits IL-13-induced dysregulation of the epidermal barrier-related proteins in skin keratinocytes via targeting to IL-13R 1 1. Mol Cell Biochem 2016:416:63-70. 